\title{
TWO TUNNELS IN COLD ICE AT 4, ooo m. ON THE BREITHORN
}

\author{
By Joel E. Fisher \\ (New York)
}

\begin{abstract}
A description is given of two tunnels, each $60-70 \mathrm{~m}$. long, one directly above the other, at 4,000 and $4,020 \mathrm{~m}$. a.s.l. excavated through cold firn and ice of the Breithorn in the Alps. The temperature rose from $-5.5^{\circ} \mathrm{C}$. at the portal to $-0.5^{\circ} \mathrm{C}$. at the rock interface $70 \mathrm{~m}$. from the portal in the upper tunnel, and from $-5 \cdot 5^{\circ} \mathrm{C}$. to $\mathrm{o}^{\circ} \mathrm{C}$. at a water reservoir $60 \mathrm{~m}$. from the portal in the lower tunnel. In both cases cracks or minute sealed crevasses, cut by the tunnel, operated to cool the ice locally below the temperature to be expected from a smooth curve. Possible origins of the water reservoir are discussed.

Small amounts of air at a moderate pressure, enclosed in small, sealed cracks and hollows, were punctured between 60 and $70 \mathrm{~m}$. from the portal in the upper tunnel. The pungent odor of the air thus released was identified as ozone (a) by its characteristic odor, (b) by its reaction on rubber, and (c) by potassium iodide starch paper tests. The source of such ozone is suspected to be minute electric sparks resulting from static electric charges built up in cold ice when it is subjected under pressure to cracking or deformation; photographs taken with exposures of $8 \mathrm{hr}$. in the upper tunnel at night apparently show such sparks.

A description is given of the appearance of cold ice, frozen to the bedrock, being forcibly tortured into streamers and bands by the movement of the entire ice body at $0.6 \mathrm{~m}$. $/ \mathrm{yr}$.
\end{abstract}

RÉsumé. On décrit 2 tunnels, ayant chacun de 60 à $70 \mathrm{~m}$ de long, placés l'un au-dessus de l'autre à 4000 et $4020 \mathrm{~m}$ d'altitude qui ont été creusés dans le névé froid et la glace du Breithorn dans les Alpes. Dans le tunnel supérieur, la température s'est élevée de $-5,5^{\circ} \mathrm{C}$ à l'entrée jusqu'à $-0,5^{\circ} \mathrm{C}$ au contact de la roche située à $70 \mathrm{~m}$; dans le tunnel inférieur, la température passe de $-5,5^{\circ} \mathrm{C}$ à $0^{\circ} \mathrm{C}$ à $60 \mathrm{~m}$ de l'entrée, dans un réservoir d'eau. Dans les deux cas, des fissures ou de petites crevasses refermées, coupées par le tunnel, ont refroidi la glace localement, en dessous de la température que l'on aurait pu attendre à partir d'une courbe régulière. On discute l'origine du réservoir d'eau.

De petites poches d'air occlus dans de petites fentes et creux refermés, ont été percées entre 60 et $70 \mathrm{~m}$ à partir de l'entrée dans le tunnel supérieur. L'odeur piquante de l'air ainsi libéré a été attribuée à l'ozone: (a) à cause de son odeur caractéristique, (b) à cause de sa réaction sur le caoutchouc, et (c) par suite de tests effectués avec un papier amidonné à l'iodure de potassium. On suppose que l'existence de l'ozone est dûe à de petites étincelles provenant de charges électriques statiques créées dans la glace froide soumise souspression aux craquements ou déformations; des photographies prises avec des temps d'exposition de 8 heures, la nuit dans le tunnel supérieur, montrent apparemment de telles étincelles.

On décrit l'aspect de la glace froide, gelée sur le lit rocheux, qui est déformée avec force en courants et bandes par suite d'un mouvement de $0,6 \mathrm{~m}$ par an de la masse entière de glace.

Zusammenfassung. Zwei Tunnels, jeder 60-70 m lang, einer unmittelbar über dem anderen in 4000 und in $4020 \mathrm{~m}$ über dem Meer, wurden durch kalten Firn und kaltes Eis am Breithorn in den Schweizer Alpen gegraben. Eine entsprechende Beschreibung wird gegeben. Im oberen Tunnel stieg die Temperatur von $-5,5^{\circ} \mathrm{C}$ am Portal bis $-0,5^{\circ}$ an der Felsgrenze $70 \mathrm{~m}$ vom Portal entfernt. Im unteren Gletscher stieg die Temperatur von $-5,5^{\circ}$ auf $\mathrm{o}^{\circ}$ bis zu einem Wasserreservoir, dass $60 \mathrm{~m}$ vom Portal entfernt ist. In beiden Fällen unterkühlten Risse oder kleine verschlossene Spalten, die durch den Tunnel aufgeschnitten wurden, örtlich das kalte Eis unter die Temperatur, die von einer ausgleichenden Kurve erwartet wurde. Die mögliche Entstehung des Wasserreservoirs wird diskutiert.

Kleine Beträge von Luft, die unter mässigem Druck steht, und in kleinen verschlossenen Rissen und Löchern eingeschlossen ist, wurden in Entfernungen zwischen 60 und $70 \mathrm{~m}$ vom Portal im oberen Tunnel angeschnitten. Der stechende Geruch der Luft, die dadurch frei wurde, konnte als Ozon identifiziert werden (a) durch seinen charakteristischen Geruch, (b) durch seine Reaktion auf Kautschuk und (c) durch Kalium Jodid Stärkepapierteste. Es wird vermutet, dass dieses Ozon durch kleine Funken entsteht, die von statischen Aufladungen herrühren; diese bauen sich im kalten Eis auf, wenn es unter Druck zum Reissen gebracht oder deformiert wird. Photographische Aufnahmen mit Expositionszeiten von 8 Stunden zeigten im oberen Tunnel bei Nacht deutlich offenbar solche Funken.

Es wird eine Beschreibung der Erscheinung von kalten Eis gegeben, das am Felsuntergrund angefroren ist und durch die Bewegung des ganzen Eiskörpers mit $0,6 \mathrm{~m} / \mathrm{J}$ ahr unter stärkstem Zwang so beansprucht wird, dass Stromlinien und Bänder entstehen.

Some 52 years ago, at Yale, the late Professor Joseph Barrell brought to my attention a paper by Willard D. Johnson (I904). Johnson described how he had descended into an open bergschrund on Mt. Lyell in the Sierras, and having noted in it copious melt water, coursing down its rock wall, yet that quantities of icicles festooned other parts of the naked rock, he concluded that the rapid alternations of melting and freezing to be found in such bergschrunds established bergschrunds in general as the specific cutting tool by which glacier cirques were created. 
It is to be noted at this point that even in the temperate Alps by far the greater part of the snow and ice areas - some 80 per cent in the Zermatt area, for example-is well above the firn line, and the névé fields of such areas are necessarily "cold" ice-snow or ice which is, in substance, below $\mathrm{o}^{\circ} \mathrm{C}$. (actually, at the mean annual temperature of the atmosphere for the altitude under study). It is to these areas of cold ice, bergschrunds or no bergschrunds, that one must look, in my opinion, to understand processes of cirque erosion, especially under former, more extensive glaciation.

With this objective in mind, I had attempted in $195^{2}$ to excavate a tunnel through to bedrock in the cold névé at the 4,ooo m. contour, under the Silbersattel, on Monte Rosa in the Pennine Alps. A year later, after that first tunnel had advanced $50 \mathrm{~m}$., the Silbersattel site had to be abandoned, due to increasing danger of ice falls to the crew. I then had a tunnel driven through the névé on the nearby Sattel of Monte Rosa, elevation 4,200 m.; this tunnel reached the rock interface (Fisher, I955). The results from that project can be summarized as follows: that "Sattel" tunnel, $92 \mathrm{~m}$. in length, penetrated névé the temperature of which

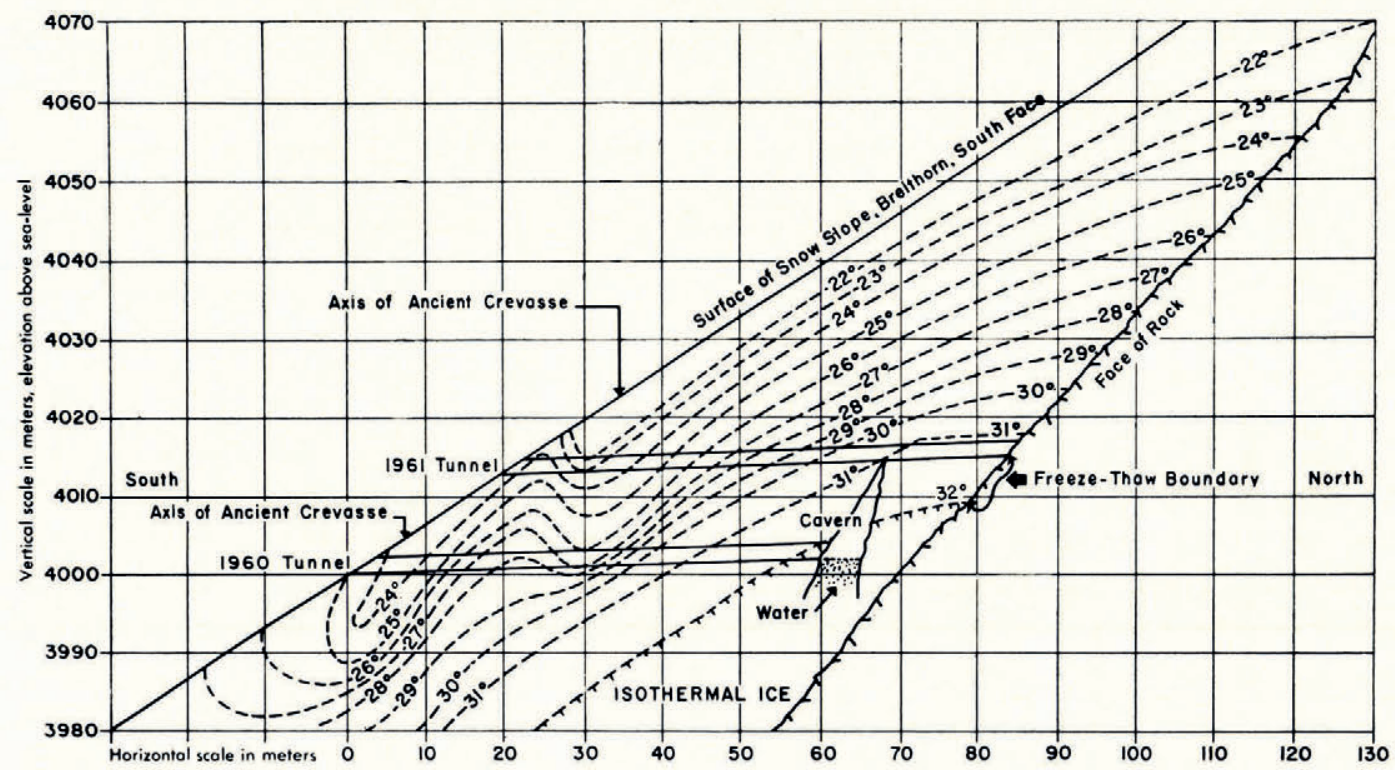

Fig. I. Cross-section on a north-south line of the south face of the Breithorn, showing both tunnels and the water reservoir. Isotherms, marked in degrees Fahrenheit, have been sketched in to join points of equal temperature in the two tunnels, and have been projected up and down through the névé by the author

rose with minor oscillations from $-14^{\circ} \mathrm{C}$. at the beginning to $-5^{\circ} \mathrm{C}$. at stations $30-40 \mathrm{~m}$. and then reverted to $-13^{\circ} \mathrm{C}$. at the rock interface, at its end. Having expected to find temperatures rising all the way to bedrock, I was confused, but eventually reconciled this surprise by the fact that the rock behind the tunnel was only a subsidiary rock ridge, the opposite side of which, not so many tens of meters horizontally through the rock beyond this tunnel heading, was one great face of bare rock, exposed to the very low mean annual atmospheric temperature appropriate to $4,200 \mathrm{~m}$., and the thermal conductivity of that solid rock, being very much higher than that of the insulating névé (rock being relatively less insulating, see Fisher (1955, p. 586)), imposes on the deep névé in contact with the rock a temperature almost as cold as that of the névé surface. 
First Breithorn Tunnel

I cast about for another site more suited to this inquiry; it needed to be at an elevation of 4,00o m., and to be safe from avalanches; it had to be a relatively wide névé field with no rock outcrops to leak in atmospheric temperatures (as on the Sattel), and with no crevasses to pipe cold air down into the ice. The intersection of the normal tourist route up the Breithorn from Zermatt with the $4,000 \mathrm{~m}$. contour, answered every requirement as a site, and ready accessibility by the Testa Grigia téléférique to a supply of excellent and intelligent guides in the Val Tournanche, ensured good progress.

So, in the spring of 1960 , this Breithorn tunnel, at an elevation of 4 , ooo m., had been driven in some $60 \mathrm{~m}$. Temperatures started at $-5.5^{\circ} \mathrm{C}$. at the portal, and with two minor alternations attributable to minor cracks leaking in a bit of cold air, temperatures warmed up to $-0.5^{\circ}$ C. at $62 \mathrm{~m}$. (see Fig. I).

On reaching this $60 \mathrm{~m}$. station in this Breithorn tunnel, my guide in charge, Armand Perron, reported to me in New York that he and his crew had unexpectedly punctured an enormous reservoir of water. To find such a phenomenon at 4,000 $\mathrm{m}$. where the mean annual temperature, and the temperature of all névé, was substantially below freezing (this location was much higher than the Jungfraujoch) was most unexpected. Water in such volume never could have percolated down from above, through twenty or more meters of névé continually well below freezing. Through the courtesy of Professor Robert P. Sharp, of the Division of Geological Sciences, California Institute of Technology, Pasadena, California, one of his assistants, Mr. William Chapple, flew over for me to the Alps in June r96o. He accompanied my guide up to the tunnel, to the very brink of the impounded reservoir, where everything was just as first reported - an enormous reservoir of water in the ice at $4,000 \mathrm{~m}$. I myself later inspected it in August i 96o, and it was indeed a sight. I estimated it contained some hundreds of thousands of liters of water, a vast cavern, perhaps $25 \mathrm{~m}$. wide (lengthwise, with the contours) and $6 \mathrm{~m}$. across (direction of the tunnel), its ceiling $3 \mathrm{~m}$. above the tunnel, its depth $6 \mathrm{~m}$. or more below the floor of the tunnel, with small icebergs sloshing around, and water obviously in constant supply, for its water had been draining out through our tunnel for two months. This latter condition required constant cleaning out of accumulations of ice on the cold ice of the tunnel floor. Flow of this impounded water out through our tunnel increased materially in the winter of $1960-6 \mathrm{I}$, a surprising contradiction to our expectation of a respite with lower water during winter temperatures. This water froze on the floor of the tunnel and required constant clearing away by the guides. When they were prevented from working by a month of severe winter blizzards, the tunnel became completely blocked up.

Haefeli and Brentani ( 1955 ) have also described similar large reservoirs of water tapped in tunneling the Jungfraujoch ice cap, and they attributed the origin of that water (Haefeli and Brentani, I955, p. 574) to melt water from above (conditioned thermodynamically). Under Jungfraujoch conditions, $600 \mathrm{~m}$. lower altitude and correspondingly warmer air temperatures than on the Breithorn, greater facility exists for percolation of surface melt water; then too, a flattish plateau above whose surface was only ro to $20 \mathrm{~m}$. above the tunnel, and an ice cover just below the freezing point, are in marked contrast with the Breithorn where the temperatures of the overlying ice were substantially colder, and the overburden of ice was two to five times that on the Jungfraujoch. Also the steep Breithorn slope invited whatever melt water appeared to run downhill, rather than seek percolation through substantial thicknesses of cold névé. In ig6r, no surface-piercing crevasses or bergschrunds existed on that Breithorn south face, even well below the 4,000 $\mathrm{m}$. tunnel contour, and none had existed during the $53 \mathrm{yr}$. since I first came to know this Breithorn area. (In September 1962, for the first time in the memory of guides, a surface-piercing crevasse did open up on that slope, but even that was $20 \mathrm{~m}$. below the tunnel level.)

Water supply deep within this steep Breithorn face at 4,ooo m. could not, in my judgement, conceivably originate from trickles of surface melt water from above. Why it should increase in 
winter posed a question, too. I can only offer the thought that this water filled an ancient (long since covered) bergschrund; that this water itself came from below, from the basal isothermal sole of the vast Breithorn plateau; the rock floor of which lay $300 \mathrm{~m}$. lower down, and that this water was forced through those interior basal layers of isothermal ice, close against the rock bed of the glacier, up to the $4,000 \mathrm{~m}$. level by artesian well principles; that is, the weight of the overlying névé, reaching up to 4, $100 \mathrm{~m}$. on that Breithorn south face (i.e. I $00 \mathrm{~m}$. higher than the tunnel), was the effective load, and the added accumulation of winter snowfall on it served to raise the net water pressure within the Breithorn plateau névé sufficiently to force water several inches higher above the $4,000 \mathrm{~m}$. level, which seemed to have been the point of summertime equilibrium.

Having myself visited the Jungfraujoch plateau many times, most recently in September I 962 , I remain doubtful how the tens of thousands of liters of water found by Dr. Haefeli in his Jungfraujoch crevasses could have accumulated from surface melt water. In my opinion, I would think that of the melt and rain water, some small amount only would percolate into these closed crevasses, but most of it would flow off the Jungfraujoch plateau surface into the open crevasses some hundred meters down towards the Guggigletscher, there to accumulate, and on occasion to be sealed in by closing, and eventually to be forced back up under the Jungfraujoch plateau by artesian processes similar to those envisaged on the Breithorn. The existence of cold ice in actual physical contact with bedrock under the very highest area of the Jungfraujoch plateau, $600 \mathrm{~m}$. lower than on the Breithorn, as reported, may be due to these same conditions as on my "Sattel" tunnel, extra cold temperatures being piped down under the ice by the superior thermal conductivity of nearby outcropping rocks, with conductivity greater than that of névé. I make the suggestion that normally existing isothermal ice (the elevation of the Jungfraujoch hardly suffices for true all-the-way-through cold névé) offers channels in areas uncontaminated by extra cold piped in through rocks by which such water may be forced up from the Guggi area.

If that is the correct interpretation, it was a unique bit of good fortune that we selected the site of this 1960 tunnel at just exactly that critical level where we could unexpectedly observe this interplay of hydrostatic forces and of snow economy.

\section{Second Breithorn Tunnel}

The decision having been forced on us by the closing up of this i 960 Breithorn tunnel, we drove a fourth tunnel during the early months of $196 \mathrm{r}$ parallel to, and $20 \mathrm{~m}$. vertically above, the ig6o tunnel. The temperature ranges of both tunnels are shown in Figure I.

This second Breithorn tunnel, as planned, drove through just over the ceiling of the water reservoir - it was possible to hear the ice falling into the water through occasional cracks - nor should I fail to mention that in all these tunnels, cracks, and small crevasses in the ice are very frequent, in fact far more frequent than ever to be expected from the photogenically smooth surfaces of the wind-blown overlying snow fields. Incidentally, the dry summer of I 962 etched out several surface crevasses, a feature never before visible on the south face of the Breithorn. They were clearly the outcrops of some of these concealed cracks which had been intercepted by the tunnel. All, however, were below the level of the new tunnel.

Work progressed rapidly, and in June I96I, my guide, Perron, reported another unexpected find, this time at $60 \mathrm{~m}$. from the portal (i.e. well beyond the water reservoir area) in ice continuously below $-0.5^{\circ} \mathrm{C}$. His working party had been puncturing small inclusions of "air", which "popped", as he said, "like the popping of a child's balloon", and at the same time, they noticed a smell, "like a hospital smell", or a gas, like, in a homely way, "the smell in a long-closed house". They wondered whether the smell might be poisonous. The rock interface was finally reached, a few meters beyond where this "odor" was found. I visited the tunnel a month later (August I96r) and the "smell" still persisted. I identified it by odor, subject to confirmation, as ozone; I will describe confirmatory tests below. 
The appearance of the ice at the rock interface was unique. As shown in Figures 2 and 3 , the ice is drawn out, as though on a rack in a medieval torture chamber, as it is pulled downhill, slowly and relentlessly, under the pressure of an overlay of a $100 \mathrm{~m}$. of névé uphill. Measurements of movement, over a period of several autumn months, indicated a displacement of about $60 \mathrm{~cm}$. $/ \mathrm{yr}$. for the ice, with respect to the rock.

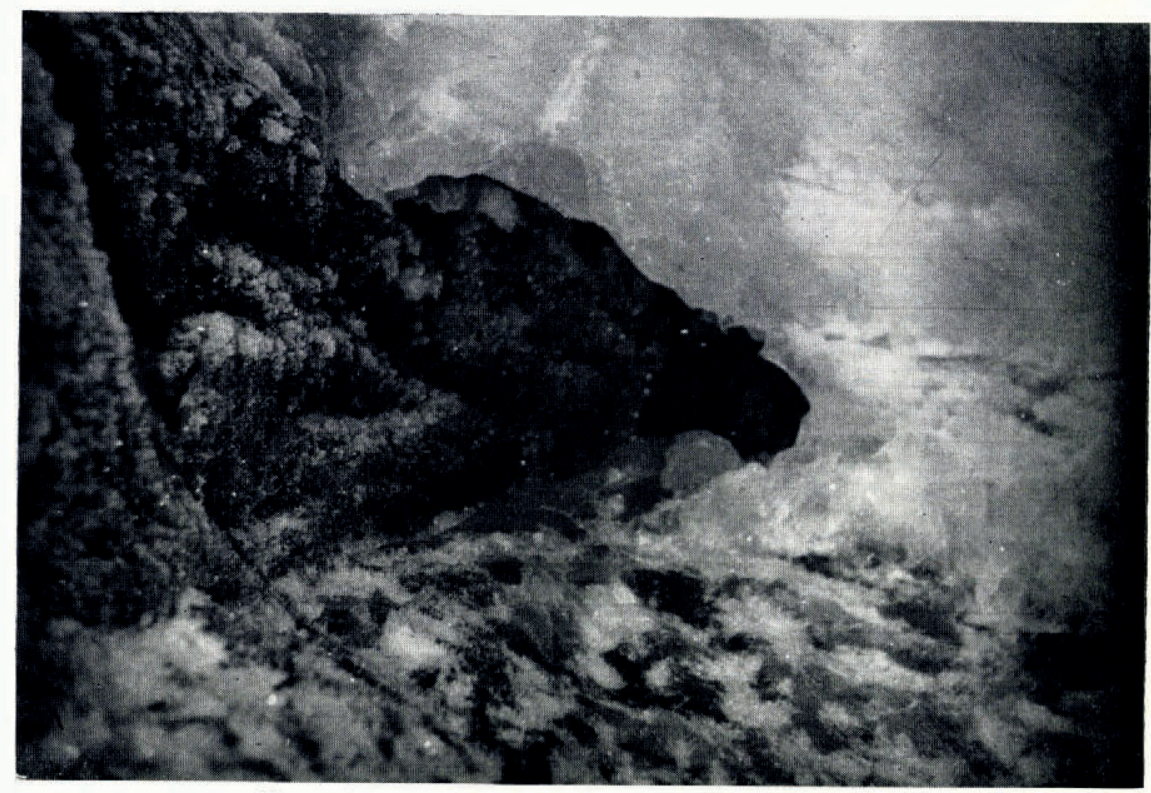

Fig. 2. Contact of ice and rock at $65 \mathrm{~m}$. in the upper tunnel

I personally extracted from the ice a small rock, about $\mathrm{s}$ oo $\mathrm{g}$. in weight, a meter from the rock interface; it had obviously been plucked from the live rock by the ice, powerfully adhering to it everywhere by freeze. No other rocks were found at any place during excavation, nor was there any substance found suitable for ${ }^{14} \mathrm{C}$ analysis.

\section{Discuussion}

We can now look back over half a century to W. D. Johnson's bergschrund cirque-erosion hypothesis mentioned above. Johnson, before the era of American interest in mountain climbing, apparently did not have any acquaintance with the majestic ice fields of the Canadian Rockies, Alaska, or the Alps. Our own Sierras possessed only very small glaciers, and he could have had no knowledge of the overwhelming proportion (above 80 per cent) of cold-ice areas characteristic of Alpine type glaciers, so he can be pardoned for having attached undue importance to his observation of local melt water and icicles in close association in what was really a doll's-house model of a full-scale bergschrund. So far as I have read, no one at that time had ventured the theory of plucking as contributing to glacier erosion. Nevertheless, in my opinion, Johnson was correct in his "alternating temperature" principle, and he must be considered as the originator of the theory of oscillations between freeze and melt as the fundamental key to glacier erosion of headwalls; only, such oscillations are on cycles of centuries instead of hours. A good perspective on times of processes is given by Carey (1962).

Of course, deep within the entrails of the majestic cold-ice accumulation areas, in the Alps and elsewhere, there can be no daily fluctuation of temperature at the site of rock contact fluctuation between truly cold ice and ice at the pressure-melting point. 
There is, however, within the ice of every such area (near bergschrunds) a contour line separating true cold ice above it from isothermal ice below it. A major bergschrund typically marks that contour. The cold ice is cold by reason of exposure to cold atmosphere.

The heat source of the adjoining isothermal area, as I set forth in an earlier paper (Fisher, r955) is a combination of the flow upwards into it of internal heat of the earth, and the release within it of heat of friction of the moving glacier, as also mentioned above. The first has been measured a vast number of times and is in the order of $30 \mathrm{cal} . / \mathrm{cm} .^{2} \mathrm{yr}$. The second source can be quite readily approximated for any simple glacier whose velocity is small (i.e. whose kinetic energy of motion approximates to zero) because the total heat of friction will be approximately equal to the thermal equivalent of the total gravitational potential energy of the vertical column of ice lying above. This is approximately true, as almost all friction of motion occurs in the basal levels of the ice.

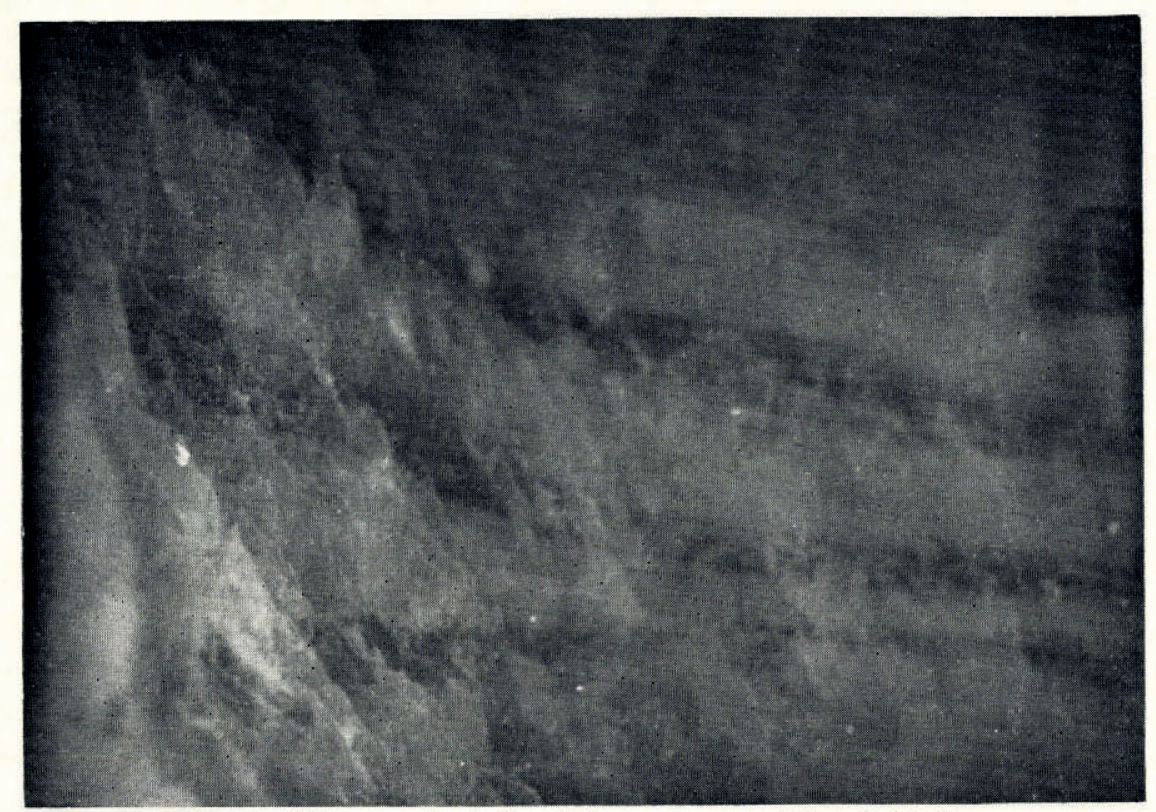

Fig. 3. Flow pattern in the ice within a meter or so of the rock interface

To reinstate W. D. Johnson's hypothesis, it will be clear that if the internal heat flow of the earth itself varies over long periods (it does vary from region to region, and presumably must vary, locally, over periods of time), or if the hydrostatic head of ice varies, due to varying overlying snowfall accumulations, or if the mean annual temperature of the local atmosphere changes the location of this interior ice-thermal boundary in its contact with bedrock, then the location of the major bergschrunds will move up or down. The resulting long term oscillations of the freeze-thaw boundary plane, the biting teeth of a glacier, exist, only on a much larger scale than Johnson foresaw, for periods of such oscillation would seem to be hundreds of years, not daily as he visualized on Mt. Lyell.

It is the writer's opinion that every glacial era, when in long-term equilibrium, will develop its cold glaciers to such thickness that, however cold their surfaces, their sole, their basal ice, will be at pressure-melting point, and there must exist, at some point on their beds, a boundary between cold ice, frozen to the bedrock, and wet isothermal ice. This boundary is invited by external conditions to oscillate slowly back and forth, with powerful shattering and removal of rock as a result. 
To revert to the odor reported by the guides. During the winter of $196 \mathrm{I}-62$ I confirmed this was ozone by exposing lengths of (dentist's) elastic rubber in the end of the tunnel, and in the valley below, each weighted moderately, and repeated this test a second time (see Fig. 4). The rubber within the tunnel lost its elasticity as measured by the elongations considerably faster than the rubber in the valley; further, the "tunnel" rubber suffered severe pitting while the "valley" rubber was unpitted. This pitting and loss of elasticity of the rubber exposed in the tunnel is characteristic of ozone action on rubber. Figure 4 shows a photograph of samples of both after six months' exposure.

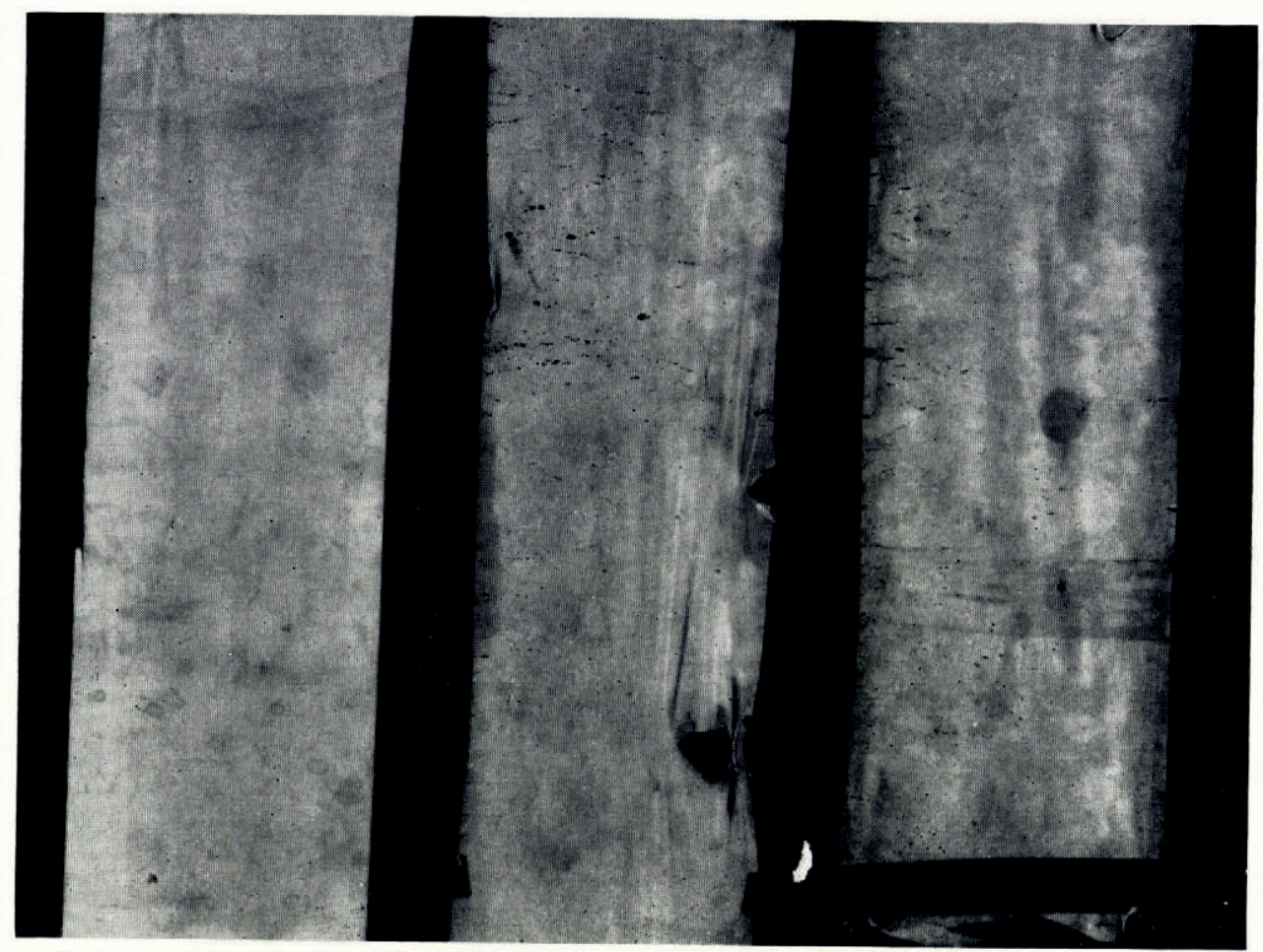

Fig. 4. Specimens of stretched rubber. The left-hand strip was exposed in the valley for six months, the other two strips were exposed in the tunnel. Note the pitting of the tunnel rubber, characteristic of the action of ozone

In September i 962 , on revisiting the tunnel, I brought along for further verification a gas analysis apparatus kindly supplied to me by Professor Victor H. Regener of the University of New Mexico, Albuquerque. Designed particularly for on-the-spot qualitative identification of ozone, it consisted, in essence, of a glass vessel $\left(c .25 \mathrm{~cm} .{ }^{3}\right.$ in volume) containing $10 \mathrm{~cm} .{ }^{3}$ of Io per cent solution of potassium iodide in doubly distilled water. A standard starch paper was placed in the potassium iodide solution, and air could be pumped through the solution, at a controlled rate, by squeezing a rubber bulb. If more than the normal concentration of ozone were present, iodine released by such ozone should cause the starch paper to turn from white through pink and lavender to deep blue, depending on the concentration of ozone. Tests with this outside the tunnel gave no color to the starch paper after 300 squeezings of the rubber bulb. That served as a null check. Repeated tests close up to the tunnel heading, each produced a very distinct pink color in the starch paper after Ioo squeezings of the rubber bulb. Qualified chemists have also examined samples of this pink discolored starch paper, and stated that, under conditions of the tests, it indicated an abnormal amount of ozone or other 
oxidizing agent in the air in the tunnel. I am satisfied, from smell, from rubber pitting, and from the iodine test, that ozone is found deep within the ice of cold ice glaciers such as this.

My best explanation of the origin of this ozone is that this cold ice (dielectric), develops electric charges, partly by deformation in its "torture chamber" as it is dragged along over the rock, and partly by physical cracking, and that minute sparks resulting from these static electric charges ionize air entrapped in that same ice. This ice has a density of about $0.82-0.85 \mathrm{~g} . / \mathrm{cm} .{ }^{3}$, less than $0.9^{2} \mathrm{~g} . / \mathrm{cm} .{ }^{3}$ on account of included air. The report of Perron, describing the escape of air under pressure as his work advanced, unwittingly confirmed that entrapped air, actually under some pressure, is available for ionization into ozone if and when static electricity develops. I have tried to verify this "static electric charge". I had all-nightlong time exposure photographs made of the ice, decp within the tunnel, up near the rock interface; on enlarging these photographs 25 diameters, it is possible to identify half a dozen irregular sharp white markings on the enlargements, definitely not imperfections in the film, and far too large for emulsion grain. While I am not reproducing these "spark photographs" here because I fear they would not show up sharply in reproduction, I will be glad to loan a copy of the enlargement to any reader who might be interested. Those irregular white marks record, in my opinion, minute static electric sparks in the ice.

I also took a gold-leaf electroscope up to the tunnel, but gold-leaf electroscopes do not take kindly to a combination of travel by air, motor, téléférique and foot, nor is the dark, cold interior of an ice tunnel convenient for attaching a new piece of gold-leaf. I will try again.

I will conclude with saying that I hope to keep the tunnel cleaned out for one more year, to be accessible for examination by anyone interested. Armand Perron, my guide in Val Tournanche, will be very happy to accompany anyone as guide.

MS. received 23 October 1962

\section{REFERENCES}

Carey, S. W. 1962. Scale of geotectonic phenomena. Fournal of the Geological Society of India, Vol. 3, p. 97-105. [Also published as University of Tasmania. Department of Geology. Publication 103.]

Fisher, J. E. 1955. Internal temperatures of a cold glacier and conclusions therefrom. Fournal of Glaciology, Vol. 2,

No. 18, p. 582-91.
Haefeli, R., and Brentani, F. 1955. Observations in a cold ice cap. Journal of Glaciology, Vol. 2, No. 18, p. 57 1-81. Johnson, W. D. I904. The profile of maturity in Alpine glacial erosion. Journal of Geology, Vol. 12, No. 7, p. 569-78. 